\title{
213-OR: Obesity-Induced Astrogliosis Is Regulated by the Diabesity Factor HMG2OA
}

Presentation in Diabetes · June 2020

DOI: 10.2337/db20-213-OR

CITATIONS

0

13 authors, including:

Esther Fuente-Martin

11. Andalusian Molecular Biology and Regenerative Medicine Centre

43 PUBLICATIONS 1,022 CITATIONS

SEE PROFILE

Nadia Cobo-Vuilleumier

Spanish National Research Council

58 PUBLICATIONS 598 CITATIONS

SEE PROFILE

Some of the authors of this publication are also working on these related projects:

Project High-Fat Diet and ER alpha View project

Project Cannabinoid-based neurogenesis and neuroanatomy View project
READS

20

Petra I. Lorenzo

Andalusian Molecular Biology and Regenerative Medicine Centre 89 PUBLICATIONS 673 CITATIONS

SEE PROFILE

Jose Antonio Guerrero-Martinez

Andalusian Molecular Biology and Regenerative Medicine Centre

39 PUBLICATIONS 76 CITATIONS

SEE PROFILE 


\title{
$\Delta$ A
}

Oral Presentations: Integrated Physiology/Obesity

\section{3-OR: Obesity-Induced Astrogliosis Is Regulated by the Diabesity Factor HMG20A}

JOSE M. MELLADO-GIL, ESTHER FUENTE-MARTIN, PETRA I. LORENZO, NADIA COBO-VUILLEUMIER, JOSE A. GUERRERO-MARTÍNEZ, SILVANA Y. ROMERO-ZERBO, JAIME M. FRANCO, JESÚS ÁNGEL PEREZ-CABELLO, MANUEL ALVAREZ-DOLADO, DAVID POZO, FRANCISCO J. BERMUDEZ-SILVA, JOSE C. REYES and BENOIT R. GAUTHIER

+ Author Affiliations

Diabetes 2020 Jun; 69(Supplement 1): -. https://doi.org/10.2337/db20-213-OR

Check for updates

$\Theta$ Previous

Article Info \& Metrics

\begin{abstract}
It is well established that systemic glucose homeostasis is imparted by an intricate cross-talk among several organs including the central nervous system (CNS) and pancreatic islets. In analogy to islet beta cells, hypothalamic astrocytes are glucose sensors that facilitate the CNS response to changing metabolic environment. Therefore, astrocytes and beta cells may share a common genetic signature implicated in coupling glucose metabolism to cellular output. We recently demonstrated that the diabesity factor HMG20A is essential for beta-cell functional maturity and adaptation to physiological stress (obesity, type 2 diabetes and pregnancy). As this chromatin remodelling factor also dictates CNS development, we sought to determine whether HMG20A is expressed in astrocytes and whether it potentiates astrocyte function in response to
\end{abstract}


environmental cues. We found that HMG20A is expressed in hypothalamic astrocytes and is upregulated in diet-induced obesity and glucose-intolerant mice, correlating with increased transcript levels of GFAP and IL$1 \beta$, indicative of reactive astrocytes (astrogliosis). High glucose, but not lipids, transiently decreased HMG20A expression in isolated mouse primary astrocytes. HMG20A silencing in astrocytes resulted in repression of pro-inflammatory as well as lipid and glucose metabolism genes. These pathways are up-regulated in activated astrocytes (astrogliosis) to resolve stress conditions. As such astrocyte depleted of HMG20A were more susceptible to cell death. Furthermore, motor neuron viability in astrocyte conditioned media was significantly hindered after HMG20A depletion in astrocytes. We posit that HMG20A is involved in the astrocyte polarization state. Under physiological pressure such as obesity, HMG20A expression may be transiently decreased by high glucose but long-term it is increased to induce astrogliosis in an attempt to preserve the neuronal network and glucose homeostasis.

Disclosure J.M. Mellado-Gil: None. E. Fuente-Martin: None. P.I. Lorenzo: None. N. Cobo-Vuilleumier: None. J.A. Guerrero-Martínez: None. S.Y. Romero-Zerbo: None. J.M. Franco: None. J. Perez-Cabello: None. M. AlvarezDolado: None. D. Pozo: None. F.J. Bermudez-Silva: None. J.C. Reyes: None. B.R. Gauthier: None.

Funding ISCIII (PI13/00593 to B.R.G.), (PI13/00309 to F.J.B-S.); Ministerio de Economia y Competidividad/Fondos FEDER (PI10/00871, PI13/00593, BFU2017-83588-P to B.R.G.); BFU2017-85420-R (to J.C.R.); (JCI-2012-12491, IJCI2015-26238 to E.F-M.); Consejería de Salud Junta de Andalucía (PI-0006-2016 to E.F-M.)

(c) 2020 by the American Diabetes Association

http://www.diabetesjournals.org/content/license

Readers may use this article as long as the work is properly cited, the use is educational and not for profit, and the work is not altered. More information is available at http://www.diabetesjournals.org/content/license.

\section{We recommend}

The microRNA 199a Family Is Regulated by Glucose Levels in Pancreatic Beta Cells JOAO PEDRO WERNECK DE CASTRO et al., Diabetes, 2018

Disruption of Lipid Uptake in Astroglia Exacerbates Diet-Induced Obesity Yuanqing Gao et al., Diabetes, 2017

2013-P: Parkin Is Dispensable in Pancreatic Beta Cells and Adipocytes for Metabolic Homeostasis GEMMA PEARSON et al., Diabetes, 2019

beta-cell glucotoxicity in the Psammomys obesus model of type 2 diabetes.
Intestinal lysozyme liberates Nod1 ligands from microbes to direct insulin trafficking in pancreatic beta cells

Qin Zhang et al., Cell Research, 2019

Microbiota guides insulin trafficking in beta cells Ozren Stojanović et al., Cell Research, 2019

Team IDs MicroRNA Tie Between Obesity and Type 2 Diabetes Features

GenomeWeb, 2013

Jackson Lab Team Sequences Single Cells to ID Diabetes-Related Gene Expression Changes GenomeWeb, 2016

G Leibowitz et al., Diabetes, 2001 
2076-P: Increased Gap Junction Coupling in the Islet of Langerhans following Caloric Restriction

MARIA C. AMARAL et al., Diabetes, 2020
Maternal Heart Health Shown to Predict Cardiovascular Disease Onset in Offspring Cardiology Advisor, 2020

\section{Powered by TREND MD}

I consent to the use of Google Analytics and related cookies across the TrendMD network (widget, website, blog). Learn more

Yes No

$\Theta$ Previous

^ Back to top

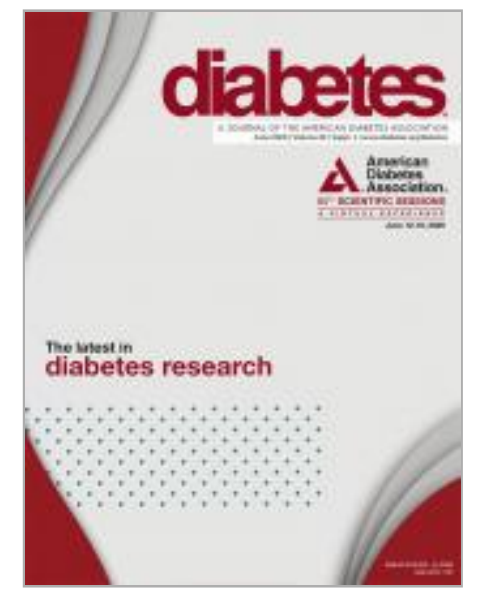

\section{In this Issue}

June 2020, 69(Supplement 1)

Table of Contents

Index by Author

Search this issue

Q

Sign up to receive current issue alerts

View Selected Citations (0) 
(- Article Alerts

$\rightarrow$ Share

Email Article

(C) Request Permissions

- Citation Tools

Tweet

+ Add to Selected Citations

Me gusta 0

\section{- Related Articles}

\section{No related articles found.}

- Cited By...

- More in this TOC Section 


\section{- Similar Articles}

\section{Navigate}

Current Issue

Online Ahead of Print

Scientific Sessions Abstracts

Collections

Archives

Submit

Subscribe

Email Alerts

RSS Feeds

\section{More Information}

About the Journal

Instructions for Authors

Journal Policies

Reprints and Permissions

Advertising

Privacy Policy: ADA Journals

Copyright Notice/Public Access Policy

Contact Us

\section{Other ADA Resources}

Diabetes Care

Clinical Diabetes

Diabetes Spectrum

Scientific Sessions Abstracts

Standards of Medical Care in Diabetes

BMJ Open - Diabetes Research \& Care

Professional Books

Diabetes Forecast

DiabetesJournals.org

Diabetes Core Update

ADA's DiabetesPro

ADA Member Directory

Diabetes.org 
(C) 2021 by the American Diabetes Association. Diabetes Print ISSN: 0012-1797, Online ISSN: 1939-327X. 